\title{
Strategy of Non Formal Music Education in Disruptive Era
}

\author{
Meyltsan Herbert Maragani ${ }^{1}$, Stefanny Mersiany Pandaleke ${ }^{2}$, Markus Wibowo ${ }^{3}$ \\ Institut Agama Kristen Negeri Manado, Indonesia \\ ilzanmaragani@gmail.com¹,pandaleke_stefanny@yahoo.co.id², wibowomarkus@iakn-manado.ac.id³
}

\begin{abstract}
The purpose of this research is to find and describe the strategies of non- formal music education in disruptive era that is focused on strategies related to the learning system applied to music course institutions. In disruptive era, the hybridization of music learning was no longer a taboo thing to do. Transformation or incorporation of teaching and learning process that used to be face-to-face has changed to online system. In addition, the development of Massive Open Online Courses (MOOCs) also has a major influence on the music education disruption. This research used descriptive qualitative method with data collection techniques through observation, interviews and document studies. Data analysis technique used interactive model analysis step. The results of the research explained that the strategy implemented include the identification of community needs, the implementation of music learning programs with methods and procedures that involve the use of technology and evaluation through the level of student skill and student performance. Encounter disruptive era, the combination of conventional methods with use the technology is an important factor to strategy of non-formal music education.
\end{abstract}

Keywords: Strategy of Non Formal Education, Music Education, Disruptive Era.

\section{Introduction}

Art should be the basis of education [1], a statement made by Plato as a form of affirmation of the relationship between art and education. Music, as one of the branches of art, occupies a crucial position in educational culture. Music in education and education through music is a concept of music education that has been carried out in the context of formal and non-formal education. In addition to developing musical skills, music education generally seeks to develop, improve and awaken musical feelings so that students can experience musical experience.

The presence of the industrial revolution 4.0 era influences one's lifestyle, how to work and one's relationships with others, including the world of education. The industrial revolution

4.0 was marked by the emergence of technological in many sectors, including robotics, artificial intelligence, nanotechnology, quantum computing, biotechnology, the Internet of Things (IoT) and 3D printing [2]. As the most influential printer of the industrial revolution 4.0 , IoT has the potential to change the understanding of how things are connected and give a big influence on the development of the world. Industry era 4.0 offers new opportunities for education so that it encourages innovations in the development of education, including music education. 
Disruption is a very popular word in this era since it was introduced by Clayton $\mathrm{M}$. Christensen in 1997. This word has become popular, along with various developments, especially in the realm of technology which is also called the industrial revolution 4.0, marked by the emergence of various applications information technology that is able to change the order of human life at this time. These changes has spread to various sectors of human life, ranging from changes in how to live, how to work, how to socialize or communicate to how to learn. In fact, Kasali in his book states that, disruption is a revolution [3].

Correspondingly, the phenomenon of disruption has also go into the world of education. Disruption, in the context of education basically occurs because of changes in several aspects such as generation changes (student), namely a new generation that raises a "gap" with the previous generation. In addition, the changes of family side (parents) means an increase the communitiy's economy which causes an increase in needs, including education needs that cause increased homeschooling activities. Then demand for skills, namely the dicrepancy between the things obtained in schools with the skills needed in the working world, as well as changes in the realm of technology that are very fast and greatly affect changes in how to learn fundamentally [4]. With the development in the realm of technology, there is a change or reshaping in education system. These changes occur along with the emergence of various technological innovations that provide new space in education world. The existence of these innovations, bringing a new culture in education world. The development of the Internet of Things (IoT) or also called the Internet of People (IoP), has led to data or information retrieval systems that used to be accessible through books or other print media, now it has switched to digital systems. That way, learning systems that are more centered on students with the use of current technology, have made students able to obtain knowledge and information more and more quickly than what can be obtained in the classroom.

The phenomenon of hybridization of the process of learning music becomes a common thing that happens in the disruptive era. Initially music learning was carried out through faceto-face learning process, has been transformed into an online learning system. The development of Massive Open Online Courses (MOOCs) has become a major influence on the disruption of music education. This has become a major challenge for music education implementing institutions, both formal and non-formal institutions. As stated by Gunanto in his research that the challenge for the College of Arts in the era of the industrial revolution 4.0 in developing science and expertise in the arts and culture lies in the willingness, ability and creativity of using digital media technology as media of leaning [5].

Non formal education as stated by Widodo, is an educational activity carried out systematically outside the formal education framework that provides the learning types for a group, both adults and children, including music learning. Non formal education has different characteristics from formal education. This is due to differences in learning objectives, environment, culture, level of knowledge and so on. The characteristics of non formal education are: relatively short time; thematic; there is no systemic level; age varies; practical orientation; materials are varied nd practical; is the fulfillment of learning needs; and not concerned with qualifications [6].

Non formal education basically develops based on human learning needs. This indicates that non formal education is more dynamically adjusting to the needs and humans learning styles. Therefore, responding to changes in disruptive era, non formal education as an implementer of educational activities, has a very important role. This is because the nature of non formal education is more dynamic and open so that it can be easier to adapt and develop various strategies in the implementation of educational activities. 
This study seeks to uncover how the strategies of non formal music education are facing the current disruption era. The strategy in question is related to the whole music learning system implemented in the music institution. The purpose of this study is to find and describe the strategies of non formal music education in disruption era. To frame this research, then the analysis related to the topic is based on the main theories of the basic teaching and learning strategies proposed by Djamarah and Zain includes: (1) identifying and determining the specifications and qualifications of the behavior and personality changes of students as expected; (2) teaching and learning approach system based on the aspirations and outlook on life of the community; (3) determination of procedures, methods and teaching and learning techniques that are considered the most appropriate and effective; (4) setting norms and minimum limits of success or criteria and standards of success so that it can be used as a guide by teachers in evaluating the results of teaching and learning activities [7].

\section{Method}

The method used in this research is descriptive qualitative. This research was conducted at several music course institutions, including the Indonesian Music School, Manado's New Harmoni Music School, Manado's Toms Yamaha Music School and Manado's Purwacaraka with the target being examined was the implementation of music education strategies. Data collection techniques are done by observation, interviews and study documents in the form of pamphlets, notes, internet. Data collection for this study focused more on in-depth interviews with informants (music teachers), which are more like conversations than formally structured interviews. The researcher considers how the interviewees assemble and arrange answers to the phenomenon of art [8]. Data validity checking techniques are based on credibility criteria, using triangulation techniques. While the data analysis technique uses the concept of teaching and learning strategies with interactive model analysis steps that begin since data is collected, reduction, data presentation and data verification.

\section{Result and Discussion}

\subsection{Music Education in Disruptive Era}

As we known in the current disruptive era, the mixing or hybridization of learning processes is no longer a new thing to do. Combining the teaching and learning process by combining face-to-face learning with online system learning has become a common thing to do in the current education system. Call it the use of educational services such as Google Classroom in the learning process has also become a frequent thing to do. In addition, the development of Massive Open Online Courses (MOOCs) at this time also has an enormous influence on the education system in this disruptive era. Various offers of convenience provided by MOOCs have attracted the interest of many young people, especially millennials, to use education services based on E-Learning. It calls a digital Start Up in the education such as Ruang Guru which has more than 15 million users and manages 300,000 teachers who offer services in more than 100 subject areas, is proof that developments in the realm of technology have been able to change the method of people learning. Correspondingly, the development of MOOCs with all the facilities it offers has also influenced the music education system, 
especially in non-formal music education and music education institutions which are oriented to the inheritance of musical skills. As is known that music education in the context of art in education (Education In Art) is a process of music education that focuses on the inheritance of skills. The process of inheriting musical skills that were formerly carried out in the form of face-to-face training through course institutions or music schools, with the presence of MOOCs at this time has caused a shift in music learning activities. Some online platforms such as Youtube that contain video tutorials, have become an option for someone who wants to learn music. Moreover, the presence of music learning platforms such as Music.Id as well as several music education service provider websites that have many users, which provide application-based music learning services with a systematic curriculum and are equipped with experienced instructors in the music field become a new trend in music education. With these phenomena, there is a technological determinism that has occurred in society in this era, namely how technology has been able to change people's actions and their ways of life [9]. Therefore, in the face of technological change or determinism in society, the need for a surefire effort or strategy that must be done especially for non-formal music education institutions and music education institutions that are oriented to the inheritance of musical skills, so that the process of implementing music education can continue and remain relevant with society needs.

\subsection{Strategy of Non Formal Music Education in Disruptiv Era}

Non formal music education institution is an institution that offers music teaching and learning process with methods, curriculum and techniques of learning music efficiently and effectively according to each institution. Music learning in question is how a person learns to play musical instruments so as to produce musical skills and abilities that can be used in the midst of community activities. However, the passage of the era of disruption requires nonformal music education institutions or institutions of music courses to make innovations to maintain existence in the real world. As explained earlier, the era of disruption has opened opportunities for the education world to abandon conventional methods, namely face-to-face, to be replaced by online systems.

Music education efforts in cyberspace can cause a decrease in people's interest to study music in the real world, especially in music course institutions. This was also emphasized by Kasali [3] that businesses operating in cyberspace with widely spread actors could drive prices down. Technology will replace old methods that seem complicated with methods that are fast paced. In order to respond to this, non-formal music education institutions implement music teaching and learning strategies in facing the era of the industrial revolution 4.0. The strategy was designed by music course institutions as an effort to achieve goals by applying patterns of activities of teachers and students to achieve the goals of the music institution.

\subsection{Object and Student Needs Identification}

Consumer needs related to music courses today are certainly different from the needs of consumers ten or twenty years ago. The intended consumers are prospective students (children and adults) as well as parents of students who want their children to have musical ability. The mindset created in the era of disruption is a mindset that is fast paced, responsive in responding. Likewise with students and parents who think playing music can be done instantly without requiring a fairly long process. In fact, to achieve musical skills aprocess is needed in accordance with the intentions and abilities of each person. 
This phenomenon makes music course institutions have to identify the needs of students so that they are right on target when carrying out teaching and learning activities. Identification is carried out related to the age of prospective students. Based on data from several music course institutions, the age of the most widely followed courses is the age of elementary school children, which is 6-11 years. In addition, there are also adults who take music courses with a number smaller than the age of children. Of course, students with different age ranges, produce different musical needs.

Non-formal music education institutions answer this with the distribution of material based on age. Children aged 3-5 years can get preparation material before getting the core material. As for adults, get material according to their musical needs. But there are also adults who get material following the curriculum of each course institution. Curriculum evaluation is also mandatory at music courses. Given the growing development of the use of digital media and technology today, the music course institute is making collaboration between conventional methods and the use of technology.

In addition to age classification, music course institutions also see the need for music with various instruments. Formerly offering classical piano learning only, now has opened piano pop and electone courses. The average music course institute offers courses in several musical instruments, including piano, violin, guitar, drums, vocals, keyboard / electone, music group, which are divided into classical and pop genres. This is one of the efforts of music course institutions to answer the music needs of the community. Associated with the concept of strategy, the music course institute has implemented the first step as one of the basic strategies, namely identifying and determining the qualifications of students and the changes that occur in society.

\subsection{Music Teaching and Learning Approach}

To achieve the target effectively, choosing a learning approach is one of the strategies that must be implemented by non-formal music education institutions. It has been explained before, that music course institutions identify targets related to student needs in the field. Therefore, the approach to teaching and learning music used must be in accordance with the needs of the community. As stated by Ganap, art education is experiencing rapid development, which always requires the discovery of various new methods of art creation and motivational approaches to art [10].

Based on the data that founded in music course institutions, the approach to teaching and learning music applied is the approach to learning music by using and even applying technology in learning, without leaving the learning approach directly through the process of teacher and student interaction. This way of learning is applied to answer the demands of the era of disruption. This was assessed when carrying out the process of identifying musical needs in the community. Various learning instruments are offered to the community by the use of technology in them.

An example of the use of technology in the process of teaching and learning music in course institutions is the use of Music Technology in piano learning. Learning music theory is not only taught manually, but using music applications, such as finale and cybelius. This is an example of a music learning approach using technology implemented at the Indonesian Music School. Another example is the use of song recordings offered by music courses to students, as well as etude books and manual music scores. This has also been carried out at the Manado Music School course in Manado. How to learn music like this explains that students are given the opportunity to learn music independently through the boundaries of practical activities 
conducted face to face.

So, the music teaching and learning approach that has been applied at each music course institution is a follow-up to the activities of identifying student needs. The needs of students in the field are musical needs that can be done quickly and continuously, so teaching and learning music approach offered in non formal music education is adjusted to the viewpoint and community needs. If it is associated with the concept used, it is in accordance with the current conditions. Music course institutions choose a teaching and learning approach based on the aspirations and viewpoint of society life.

\subsection{Method, Learning Techniques and Procedures of Music Course Institution}

The strategic component that must be carried out by non-formal music education institutions is to determine the methods, learning techniques and procedures of each institution. Of course the method applied follows the music teaching and learning approach of the institute. Music learning methods are used to motivate students to be able to apply their knowledge and skills in music. It should be explained that the method in learning music is not limited to learning music, but rather the packaging of material or content taught to students. The method used can be the same, but the packaging of the material presented is different. This is one of the strategies implemented by each music course institution in response to the era of disruption.

The observation 's fact explain that various methods that contain music teaching materials are applied in music course institutions. The method applied pays attention to the needs, interests and development of students. This was also confirmed by Suardi and Syofrianisda that modern education pays more attention to the development of all children. Knowledge remains important but better knowledge also functions in a child's life [11].

The use of technology in the era of disruption is commonly used in music learning methods in non-formal music education institutions. The Indonesian Music School offers a short-term method of learning music, which is material taught in the form of simple songs that students can play in class performance. Every month the teacher teaches a song, which is interspersed with learning the technique of playing instruments according to the song taught. Then the songs are trained and displayed in class perform activities once a month. In addition, the Indonesian Music School applies the method of learning music theory, listening and singing both manually and with the use of technology. Manually intended by drawing block notation on a book, while for the use of technology, students can learn music theory through music and YouTube applications.

New Harmoni Music School applies the Suzuki method in the process of teaching and learning music. According to guest speaker Stephen Cahyadi, who was Suzuki's senior trainer on piano instruments, the Suzuki method was applied by repeating themes from simple to rather difficult. Students are taught to listen, read and remember music so students who practice can play some songs without using scores. This method is implemented in the process of teaching and learning music, then displayed in a performance that involves students, parents, teachers and other invitations.

As for other course institutions, such as Purwacaraka Manado offers learning methods with a curriculum from Purwacarka center. The interesting thing, besides applying the method, Purwacaraka Manado also offers non-curriculum methods for adults. This was done to answer the demands of playing adult music. Adults who tend to want to develop musical skills to be used in some activities become a sign of starting a new method of learning music for this course institution. Therefore, the hobby class is for adults who want to pursue musical skills 
without sheet music notation.

Yamaha Music School Manado is a course institution with an organized curriculum and can be said to have been tested for students, especially for the classical genre. Based on observations, the Yamaha curriculum also requires students to be creative, in addition to being able to read, listen and sing for vocals. The intended creativity is that students are trained to be able to develop varied themes, both from the melody and accompaniment. Now, facing the 21 st century, Yamaha Music School offers a method of packaging material according to the demands of the era of disruption. One example, the presence of Pianoforte in studying classical piano instruments. Pianoforte is divided into 12 books which are divided into 8 grades, which contain a collection of songs that are more fun, varied and innovative. In addition, the method of learning music by listening has been implemented by the institute in the form of song recordings, which can be heard by students at any time.

Procedures offered by non-formal music education institutions generally use levels or grades that must be passed by students with different methods and packaging materials. One thing that seems to have become mandatory for non-formal music education institutions in this era, is to prioritize student performances held either annually or monthly. Student performances are no longer limited to a room, but to a shopping center, open space and encourage students to compete. Perform becomes a tangible result of the process of teaching and learning music in non-formal music education institutions. Related to the concepts used, it can be concluded that the selection of methods and procedures for teaching and learning music becomes a guide for a teacher or music instructor in carrying out his teaching assignments. Determination of music learning methods and procedures is also a guide for music course institutions that overshadow a process of learning various musical instruments.

\subsection{Evalution of Music Learning Activities}

As an educational institution, non-formal music education institutions should evaluate the ongoing learning and teaching activities. Criteria or standards of success of a student are generally measured by grade level. Grade levels usually start from grade 1, for the Yamaha curriculum starting from grade 13 to grade 6. Before entering the grade level, some music course institutions apply preparatory or preliminary material with the intention of maturing students' knowledge and skills before entering core material.

Student performance also includes part of teacher evaluations and course institutions. Through student performance, course institutions can measure the extent to which the material can be presented by students. In addition, this is also an evaluation material for parents of students. In the era of disruption, performing is mandatory to strengthen student confidence, motivate students to practice and be creative and as a tangible result of the process of teaching and learning music. The orientation of non formal music education is more towards the results without ignoring the process. Because results can be obtained when undergoing a process, both long-term and short-term processes.

Based on the explanation above which is then associated with the concept of teaching and learning strategies, it was found that non-formal music education institutions are institutions that also set a minimum threshold of success or music criteria between one student and another student. It's just that the limits of success are not absolute as applied to formal music education institutions. If in formal educational institutions, these criteria must be met as a whole, then for non-formal educational institutions, the limits of success are adjusted to the ability of music students. 


\section{Conclusion}

Non-formal music education institutions are educational institutions that provide teaching and learning activities for musical instruments. Facing a disruptive era, the world of music education has changed from conventional learning to free to innovate with the use of technology. This requires non-formal music education institutions to innovate to maintain the existence of the implementation of music education in the real world. Therefore, music course institutions need teaching and learning strategies, which include effective planning, implementation and evaluation in order to achieve goals. In this regard, the strategy adopted by non formal music education in dealing with disruptive era consists of identifying students' needs, then establishes a learning approach using digital media without leaving face-to-face learning. Part of the strategy is also applied relevant music class methods, learning techniques to design music course procedures. Student performing is a tangible result of the teaching and learning process in non-formal music education institutions. Through grades and student performances, institutions, teachers and parents can evaluate the whole process of teaching and learning music.

\section{References}

[1] Read, H. Education Through Art. London: Faber and Faber (1970).

[2] Savitri, A. Revolusi Industri 4.0 Mengubah Tantangan Menjadi Peluang di Era Disrupsi. Yogyakarta: Penerbit Genesis (2019).

[3] Kasali, R. Disruption. Jakarta: PT Gramedia Pustaka Utama (2019).

[4] Dwiningrum, Siti I.A. Culture-Based Education To Face Disruption Era. 3rd National Seminar on Educational Innovation, p. 21 (2018).

[5] Gunanto, S.G. Tantangan Perguruan Tinggi Seni Selaku Agen Pembangunan Seni dan Budaya Indonesia 4.0. Seminar Nasional Dies Natalis ke-34 ISI Yogyakarta, p. 5(2018).

[6] Widodo dan Nusantara. Building the Character of Children Through Non-Formal Education in Schools, Journal of Nonformal Education, Vol. 6 (1), p. 70-71 (2020).

[7] Djamarah, S.B dan Zain. Strategi Belajar Mengajar. Jakarta: PT Rineka Cipta(2018).

[8] Rohidi, T.R. Metodologi Penelitian Seni. Semarang: Penerbit Cipta Prima Nusantara (2011).

[9] Suratman, S. Determinisme Teknologi Komunikasi dan Globalisasi Media Terhadap Seni Budaya Indonesia, Jurnal Rekam Vol. 12 (1), pp. 33 (2016).

[10] Ganap, V. Musik dalam Kultur Pendidikan. Yogyakarta: Penerbit Thafa Media (2019).

[11] Suardi dan Syofrianisda. Belajar dan Pembelajaran. Yogyakarta: Penerbit Parama Ilmu (2018). 